\section{PŘíPRAVA ČESKÉ VERZE 11. REVIZE MEZINÁRODNÍ KLASIFIKACE NEMOCÍ}

\section{Dana Krejčová, Miroslav Zvolský, Šárka Daňková}

\section{Anotace}

Ústav zdravotnických informací a statistiky České republiky $\checkmark$ rámci projektu Národního centra pro medicínské nomenklatury a klasifikace pracuje na procesu implementace MKN-11 do českého systému zdravotní péče. $Z$ tohoto důvodu byla vytvořena Preimplementační analýza, která slouží jako informační základ pro rozhodování o zavedení MKN-11 v České republice, stanovení časového odhadu, plánování kapacit a zdrojů, vytvoření potřebných postupů atd. Ze zástupců klíčových institucí v procesu implementace byla sestavena meziresortní pracovní komise, která zajištuje přenos informací od jednotlivých institucí, zajištuje základní školení kličových osob z jednotlivých institucí, identifikuje konkrétní potřeby jednotlivých institucí/ agend pro přechod na MKN-11 a podniká kroky k její implementaci v praxi. Na překladu MKN-11 pracuje od léta 2020 interní 12 členný tým a spolupracuje s odborníky z Ústavu dějin lékařství a cizích jazyků pro zajištění správné terminologie a jazykové konzistence. První fáze překladu probíhá s využitím platformy MKN-11 od Světové zdravotnické organizace (WHO) a její finalizace je naplánována na přelom let 2021 a 2022. Ve spolupráci s odborníky jmenovanými Českou lékařskou společností J. E. Purkyně probíhá validace a ověření přeložených kapitol české verze $M K N-11$ a v závěrečné fázi zároveň budou jednotlivé kapitoly přezkoumány dalšími institucemi, jako je Ministerstvo zdravotnictví České republiky a Český statistický úřad. Dokončení české verze MKN-11 a následných revizí je plánováno na rok 2022. Ze snahy o implementaci MKN-11 do ČR vyvstala také aktivita mezinárodní spolupráce s dalšími státy (Polsko, Slovensko) a užší spolupráce se samotným WHO.

\section{Klíčová slova}

mezinárodní klasifikace nemocí, překlad, MKN-11, implementace, medicínská terminologie

\section{1 Úvod}

Mezinárodní klasifikace nemocí (MKN) je systém klasifikace onemocnění, príznaků, prríčin onemocnění a dalších stavů souvisejících se zdravím nebo kontaktem se zdravotními službami. Od roku 1994 je v České republice aktuálně platná česká verze 10. revize této klasifikace (MKN-10), jejiž příprava probíhala ve spolupráci s řadou odborníků. Přesto překlad a implementace nebyly zdaleka ideálně připraveny a realizovány i vzhledem k rozsahu a významu použití MKN-10, který v průběhu let narůstal. S některými nedostatky zavedení $\mathrm{MKN}-10$ se v kódování zdravotní péče a sběru dat potýkáme dodnes.

MKN-10 se v ČR využívá v rámci řady registrů, datových systémů a statistik, jako např. zápis příčin smrti na Listu o prohlídce zemřelého, evidence poskytnuté zdravotní péče, vykazování do Národního zdravotnického informačního systému, vykazování pracovní neschopnosti a v dalších zdravotnických systémech, má tedy široké uplatnění. $V$ současné době aktuální verze klasifikace nevyhovuje řadě požadavků jejího odborného využití. V zájmu zvýšení kvality a možností stávajících informačních systémů a sběrů dat ve zdravotnictví a $v$ zájmu mezinárodní srovnatelnosti je žádoucí přejít v budoucnosti na 11. revizi MKN.

$\mathrm{Na}$ rozdíl od předchozích revizí, které byly vytvářeny jako informační produkt v knižní podobě, MKN-11 má formu informačního standardu skládajícího se z terminologické a definiční vrstvy a principů tvorby informační struktury - kódování klinické informace. Položky klasifikace jsou v MKN-11 daleko více dopIněny klinickými textovými definicemi. Nyní zahrnuje přes 55 tisíc kódovaných položek ke kódování mortality a morbidity (Mortality and Morbidity Statistics, MMS), které jsou vybrány z rozsáhlé terminologické vrstvy tzv. Foundation obsahující více než 120 tisíc klinických termínů [1,2,3,4,5].

\section{Nástroje WHO a struktura překládaných položek v MKN-11}

V souvislosti se zaváděním MKN-11připravila Světová zdravotnická organizace (WHO) řadu nástrojů a doprovodných materiálů k jejímu užívání, jako je např. „ICD-11 Browser“ (viz Obr. 1), který umožňuje uživateli procházet strukturu lineari-

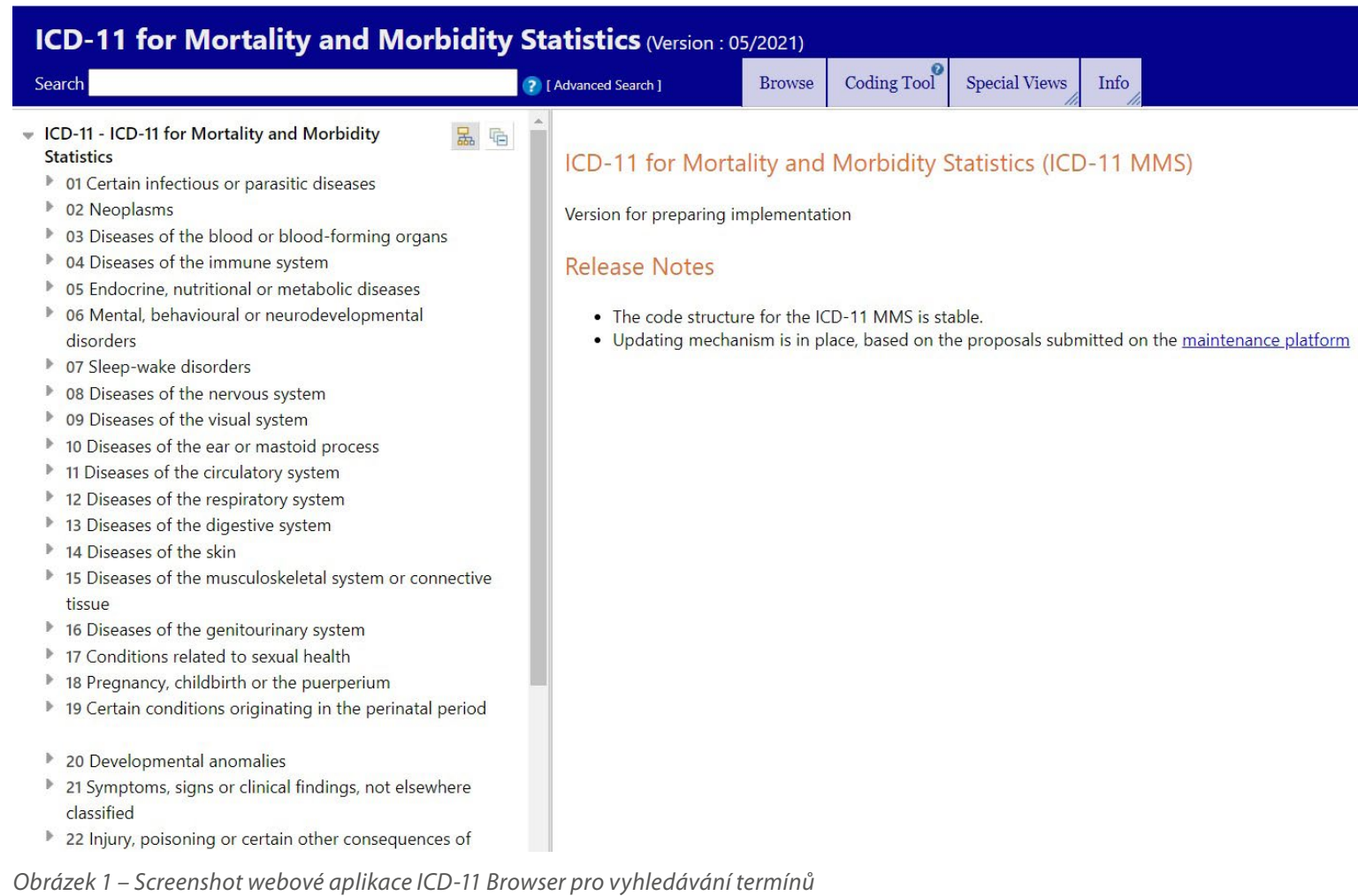


zace ICD-11 MMS a nalézt pojmy vyhledáváním termínů, anatomických struktur či dalších prvků z MKN-11 v hierarchickém stromě klasifikace. Dalšími nástroji jsou „ICD-11 Coding Tool“ usnadňující proces kódování klinické informace prohledáváním obsahu MKN-11 na základě zadávaného termínu či nástroj pro trénování kódování „ICD-11 FIT“. V rámci dostupných nástrojů byla vytvořena také "Maintenance platform", která umožňuje zobrazení základní terminologické vrstvy (Foundation), příspěvky a diskuse nad změnou obsahu a různé jazykové verze. Překlad termínů pro českou verzi probíhá $v$ datovém modelu MKN-11. Ne každou součást datového modelu MKN-11 je však nutné překládat, některé pouze odkazují na jinou část datové struktury MKN-11 [6].

\section{Překladové nástroje}

Jako překladový nástroj pro přípravu české verze je používán nástroj vytvořený WHO přesně pro tyto účely. Jedná se o tzv. Multilingual Translation Tool, který je součástí webové aplikace ICD-11 Maintenance platform (viz Obr. 2). Umožňuje např́ílad navržení překladu (pokud byl daný text překládán v jiné části MKN-11) nebo systém víceúrovňového schvalování překladu. Také přehledně zobrazuje, které části (a z kolika procent) jsou již přeloženy. Malou nevýhodou tohoto nástroje je časová náročnost managementu př́stupů pro všechny zapojené odborné i jazykové experty, anglické prostředí aplikace a nutnost proškolení všech uživatelů k práci s tímto prostředím.

Z toho důvodu bylo rozhodnuto zřídit uživatelské přístupy do platformy pouze editorům překladu a následný proces validace klinickými experty řešit exportem přeložených termínů z Maintenance platform do tabulkového souboru (ve formátu MS Office), jeho rozdělení podle kapitol a poté rozeslání jednotlivých částí expertům $\mathrm{k}$ oponentuře. Tyto samostatné části je možné následně (za dodržení původního formátování) poskládat zpět do celku a prostřednictvím WHO nahrát do Maintenance Platform $[1,2,3,4,5]$.

\section{Postup tvorby české verze}

Před zahájením tvorby české verze MKN-11 byl sestaven interní tým sestávající z pracovníků Oddělení klinických klasifikací ÚZIS ČR. Členové týmu jsou převážně lékaři či biomedicínští inženýři a disponují přehledem o medicínské terminologii. $V$ průběhu prací byl překladatelský tým doplněn o dvě expertky z Oddělení lékařské genetiky VFN a 1. LF UK, které se věnují editaci kapitoly Vývojové anomálie.

Mezi tyto členy = editory byly distribuovány kapitoly a termíny obsažené v MKN-11 a společně s tím také metodický materiál sjednocující postup překladu a seznam preferovaných českých ekvivalentů pro vybrané termíny. Tento metodický materiál je průběžně aktualizován podle výstupů a zpětné vazby workshopů pro editory (viz níže). Zároveň byl vytvořen Slovníček doporučených překladů a synonym, který má za cíl usnadnit a unifikovat práci jednotlivých editorů a následně zajistit systematické doplnění a kontrolu synonymických vyjádření v terminologii Foundation. I tento dokument je pravidelně aktualizován a doplňován jednotlivými editory o nové termíny, překlady názvů a další synonyma.

Následně proběhlo zaškolení interního týmu ohledně práce $s$ prekladatelskou platformou a překladem jednotlivých termínů.

V souvislosti se snahou o co nejvíce konzistentní tvorbu české verze bylo zavedeno pravidelné konání workshopů pro editory. Workshopy se konají každý měsíc a jejich hlavní náplní je řešení nejasných termínů a sdílení zkušeností s tvorbou české verze jednotlivých kapitol. Na workshopech je zajištěna i účast expertů z Ústavu dějin lékařství a cizích jazyků 1. LF UK, která je důležitou součástí řešení terminologie a nejasností nalezených při překladu v Maintenance platform.

Každá kapitola před předáním klinickým expertům prochází interní revizí. Tým editorů si navzájem reviduje kapitoly a jejich autoři následně zapracovávají připomínky, opravují chybné termíny, upravují texty. Tato interní revize se provádí vždy a slouží k zamezení či omezení chybovosti, konzistentnějšímu překladu a lepší kvalitě obsahu kapitol.

V průběhu tvorby české verze (s omezenou kapacitou a zásahy) a při finalizaci termínů MKN 11 po externí revizi klinickými experty a úpravě kapitol je prováděna jazyková kontrola termínů ve spolupráci s Ústavem dějin lékařství a cizích jazyků 1. LF UK zaměřená převážně na konzistenci termínů a uplatnění pravidel metodického materiálu pro překlad.

Při finalizaci podoby českých termínů dochází k jejich uspořádání do celku, kontrole integrity, kontrole shody preferovaných termínů, identifikaci přetrvávajících konfliktních překladů a jiných problémů tvorby české verze a jejich řešení. Finalizace pro-

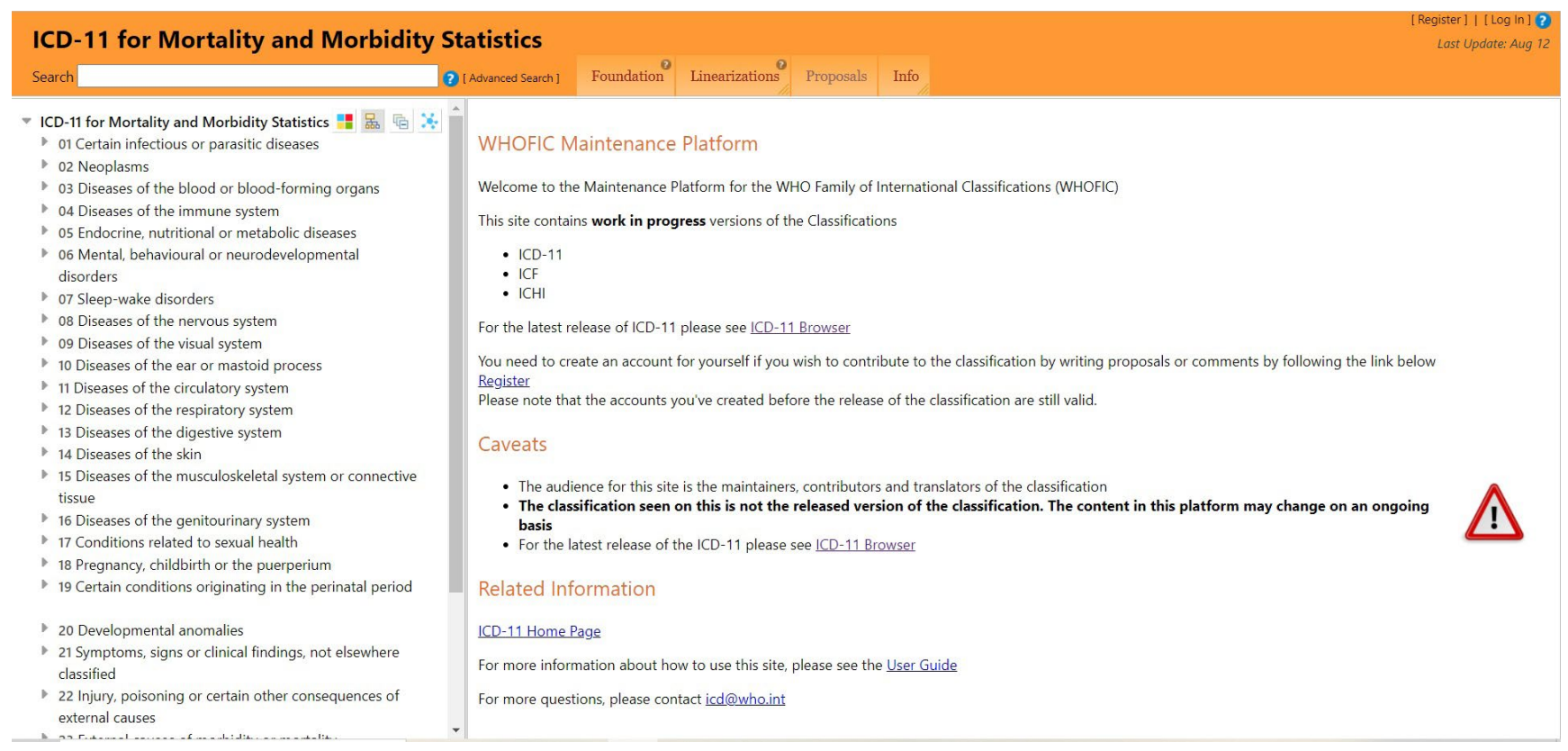

Obrázek 2 - Screenshot webové aplikace Maintenance platform obsahující mimo jiné nástroj pro préeklad Multilingual Translation Tool 
bíhá tak, že jsou připravené termíny odeslány nasmlouvaným expertům jednotlivých odborností z České lékařské společnosti Jana Evangelisty Purkyně (ČLS JEP) k revizi, zejména z hlediska správnosti a odbornosti termínů a kontroly kompletnosti. Experti mají zároveň za úkol doplnit chybějící či nejasné termíny. Jak již bylo zmíněno v kapitole 3 , pro zjednodušení práce expertů jsou termíny z Maintenance platform exportovány do tabulkového souboru (ve formátu MS Office) a poté rozeslány jednotlivé části podle odborností. Tyto zvalidované části jsou následně předány zpět editorům kapitol, kteří vypořádávají připomínky a upravují termíny v Maintenance platform. Takto připravené kapitoly na závěr prochází finální jazykovou kontrolou a stylizací jazykovými experty.

V naprostém závěru je naplánován proces „postprodukce“. $\mathrm{V}$ tomto procesu bude možno na principu zpětného nahrání tabulkového souboru (za dodržení původního formátování) prostřednictvím WHO nahrát doplňující data do Maintenance Platform. Prostřednictvím postprodukce budou doplněna synonyma a přidružené termíny, které do platformy nebyly zadány během samotné práce na překladu na základě vytvořených kombinací, což zajistí systematické zahrnutí nezbytných kombinací termínů, synonym a jejich variací a finální potřebné úpravy textu a jeho případné sjednocení, a to bez neadekvátní zátěže editorů při práci ve webovém prostředí Translation Platform [2].

\section{Harmonogram překladu}

ÚZIS ČR ve spolupráci s Univerzitou Karlovou zahájil projekt Národní centrum pro medicínské nomenklatury a klasifikace (NCMNK). Projekt byl zahájen $v$ roce 2020 a bude probíhat po dobu 36 měsíců. Výstupem jedné z klíčových aktivit projektu je právě český překlad MKN-11. Př́prava překladu, samotný překlad a následná implementace probíhají podle harmonogramu znázorněného na Obr. 3. Na následné korektury, revize a pravidelné aktualizace české verze mimo časový rámec projektu bude nutné najít další kontinuální zdroj finančních prostředků.

Původní odhad harmonogramu vytvoření české verze MKN11 byl v létě 2020 revidován zejména v souvislosti se změnou postupu $v$ úvodní části překladu obsahu MKN-11, kdy před angažováním expertů do úvodní editace dostal přednost interní tým na ÚZIS ČR a kliničtí experti jsou využiti především na validaci a doplnění české terminologie. Další úpravy harmonogramu byly zapracovány s ohledem na reálné vytížení interního týmu ÚZIS ČR jinými úkoly a s ohledem na posun zahájení

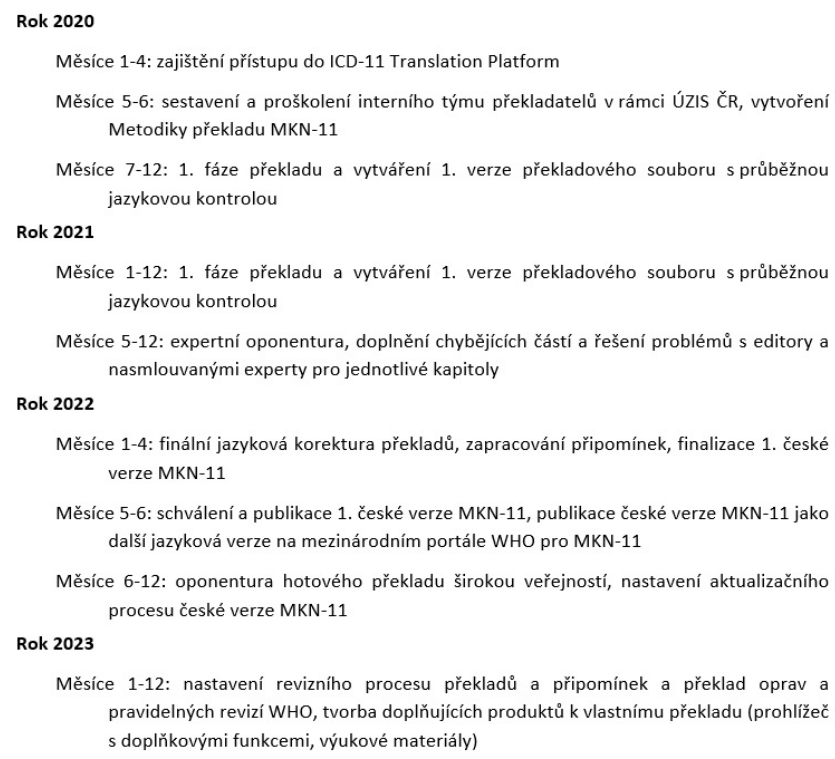

projektové spolupráce na NCMNK mezi ÚZIS ČR a UK až na červenec 2020.

Začátkem roku 2020 byly zahájeny intenzivní práce na tvorbě české verze MKN-11, zajištěny př́stupy všem překladatelům do Translation Platform, celému týmu byly distribuovány metodické materiály a proběhlo proškolení v používání platformy. Následné měsíce probíhala a stále pokračuje první fáze překladu a vytváření první verze překladového souboru, doplněné o jazykovou kontrolu expertů z Ústavu jazyků, která probíhá kontinuálně.

V roce 2021 byla zahájena také expertní oponentura nasmlouvanými experty pro jednotlivé kapitoly. Jak již bylo zmíněno výše, tato oponentura zajištuje doplnění chybějících částí a řešení problémů s editory překladu. Tento proces bude probíhat až do začátku roku 2022 s tím, jak budou jednotlivé části postupně dokončovány.

Do konce první poloviny roku 2022 je naplánována finální jazyková korektura překladů a finalizace první verze české MKN11. Ve druhé polovině roku 2022 by mělo proběhnout schválení a publikace této předběžné české verze klasifikace, následované oponenturou široké veřejnosti a $v$ neposlední řadě také nastavení aktualizačního procesu první české verze MKN-11.

V roce 2023 je následně naplánováno nastavení revizního procesu překladů a připomínek, implementace oprav a pravidelných revizí WHO a tvorba doplňujících produktů k vlastnímu překladu (prohližeč s doplňkovými funkcemi, výukové materiály) [2].

\section{Stav překladu}

V prvním kroku byl do Translation Tool nahrán soubor českých termínů MKN-10 (názvy kódovaných položek), který pokrývá asi $2 \%$ obsahu MKN-11.Z hlediska přeložených termínů linearizace MMS se jedná asi o $7 \%$ názvů kódovaných položek. I české termíny importované z MKN-10 jsou podrobeny posouzení správnosti klinickým expertem (v MKN-10 mohlo např. být sporné určení preferovaného termínu, chybný překlad nebo posouzení klinické adekvátnosti).

Dále byly přeloženy technické termíny a termíny pro webové rozhraní, které je nyní již k dispozici v českém jazyce a čítá 322 přeložených položek.

Aktuální stav a celkový objem hotového překladu je znázorněn přímo $v$ Maintenance Platform ve formě kruhového diagramu (viz Obr. 4). Pro průběžné sledování jednak počtu českých termínů, jednak kvality přeloženého obsahu a ř́zení práce na tvorbě českých termínů je využíváno exportu obsahu MKN-11 Foundation prímo z Translation Platform do formátu tabulky MS Excel, která je dále analyticky zpracována v MS Office. K datu 8. 8. 2021 je přeloženo necelých 93 tisíc termínů z celkových 133 000. Mezi tyto termíny jsou zahrnuty jak vlastní názvy diagnóz, tak i priidružená synonyma a definice.

Stav tvorby české verze dle dokončenosti kapitol je znázorněno $v$ Tab. 1 a tento stav je aktuální $k$ datu 8. 8. 2021. V tabulce jsou zobrazeny kapitoly, které v současné době prochází oponenturou klinickými experty, které již touto oponenturou prošly a také ty, které se nachází v první fázi překladu před samotnou validací.

\section{Kroky potřebné pro implementaci MKN-11 ve zdra- votnictví a dalších agendách}

MKN-11 nabízí zcela nový pohled na způsob prezentace a používání medicínské klasifikace $v$ elektronické podobě. Její možnosti jsou velmi široké a bude nutné pečlivě zvážit, jakým způsobem budou $v$ ČR realizovány.

Hlavním předpokladem $k$ úspěšné implementaci $M K N-11$ v ČR je vytvoření české verze a navazujících materiálů a pod- 




Obrázek 4 - Screenshot prèekladatelského nástroje Translation Tool se současným stavem překladu

\begin{tabular}{|c|c|c|}
\hline Č́slo kapitoly & Název kapitoly AJ & Název kapitoly ČJ \\
\hline 01 & Certain infectious or parasitic diseases & Nĕkterá infekčni a parazitárni onemocnění \\
\hline 02 & Neoplasms & Novotvary \\
\hline 03 & Diseases of the blood or blood-forming organs & Onemocněni krve a krvetvorných orgánů \\
\hline 04 & Diseases of the immune system & Onemocnění imunitniho systému \\
\hline 05 & Endocrine, nutritional or metabolic diseases & Onemocněni endokrinního systému, výživy a přeměny látek \\
\hline 06 & Mental, behavioural or neurodevelopmental disorders & Duševní, behaviorální nebo neurodevelopmentální poruchy \\
\hline 07 & Sleep-wake disorders & Poruchy spánku a bděni \\
\hline $\begin{array}{l}08 \\
09\end{array}$ & $\begin{array}{l}\text { Diseases of the nervous system } \\
\text { Diseases of the visual system }\end{array}$ & $\begin{array}{l}\text { Onemocnění nervového systému } \\
\text { Onemocnění zrakového systému }\end{array}$ \\
\hline 10 & Diseases of the ear or mastoid process & Onemocněni ucha nebo mastoidniho výběžku \\
\hline 11 & Diseases of the circulatory system & Onemocněni oběhového systému \\
\hline 12 & Diseases of the respiratory system & Onemocněni dýchacího ústrojí \\
\hline 13 & Diseases of the digestive system & Onemocněni trávicího systému \\
\hline 14 & Diseases of the skin & Onemocněni kǔže \\
\hline 15 & Diseases of the musculoskeletal system or connective tissue & Onemocnění muskuloskeletálního systému nebo pojivové tkáně \\
\hline 16 & Diseases of the genitourinary system & Onemocněni urogenitálního systému \\
\hline 17 & Conditions related to sexual health & Conditions related to sexual health \\
\hline 18 & Pregnancy, childbirth or the puerperium & Těhotenství, porod a šestinedělí \\
\hline 19 & Certain conditions originating in the perinatal period & Některé stavy vzniklé v perinatálním období \\
\hline 20 & Developmental anomalies & Vývojové anomálie \\
\hline 21 & Symptoms, signs or clinical findings, not elsewhere classified & Příznaky, znaky nebo klinické nálezy nezařazené jinde \\
\hline 22 & Injury, poisoning or certain other consequences of external causes & Poranění, otravy a některé jiné následky vnějšich přičin \\
\hline 23 & External causes of morbidity or mortality & Vnějši príičiny nemocnosti a úmrtnosti \\
\hline 24 & Factors influencing health status or contact with health services & Faktory ovlivňujici zdravotní stav a kontakt se zdravotnickými službami \\
\hline 25 & Codes for special purposes & Kódy pro speciálni účely \\
\hline 26 & Supplementary Chapter Traditional Medicine Conditions - Module I & Supplementary Chapter Traditional Medicine Conditions - Module I \\
\hline v & Supplementary section for functioning assessment & Doplňková část pro posuzováni funkčních schopností \\
\hline & Extension Codes_(dalši děleni kapitoly niže) & Extension Codes \\
\hline & Severity Scale Value & S̄everity Scale Value \\
\hline & Temporality & Temporality \\
\hline & Aetiology & Etiologie \\
\hline & Topology Scale Value & Topology Scale Value \\
\hline & Anatomy and topography & Anatomie a topografie \\
\hline & Histopathology & Histopatologie \\
\hline & $\begin{array}{l}\text { Dimensions of injury } \\
\text { Dimensions of external causes } \\
\text { Health Devices, Equipment and Supplies } \\
\text { Substances } \\
\text { Consciousness } \\
\text { Diagnosis code descriptors } \\
\text { Capacity or context } \\
\text { ICD-O } \\
\text { Extension codes of particular relevance to skin diseases }\end{array}$ & $\begin{array}{l}\text { Dimensions of injury } \\
\text { Dimensions of external causes } \\
\text { Health Devices, Equipment and Supplies } \\
\text { Substances } \\
\text { Consciousness } \\
\text { Diagnosis code descriptors } \\
\text { Capacity or context } \\
\text { MKN-O } \\
\text { Extension codes of particular relevance to skin diseases }\end{array}$ \\
\hline
\end{tabular}

hotová käpitola komplet validace jazykovými experty UK zvalidovảno ČLS JEP odesláno $\mathrm{k}$ validaci ČLS JEP probiná interni validace v procesu prekladu 
kladů pro použití v informačních systémech. Dalším předpokladem implementace MKN-11 v praxi je její základní představení a šíření povědomí o tom, jaké jsou možnosti jejího využití v odborných kruzích a mezi jejími potencionálními uživateli. Především je nutné upozornit na to, jaké jsou výhody a možnosti využití oproti MKN-10, přičemž se předpokládá, že MKN-11 v ČR nahradí MKN-10 ve všech oblastech, kde je tato doposud používána. Zároveň může MKN-11 standardizovat kódování a sémantický popis zdravotnických informací v dalších oblastech zdravotnictví.

Jednotlivé aktéry v oblasti využití a implementace MKN-11 (poskytovatele, zdravotní pojištovny, producenty informačních systémů a další) je nutné podrobně a průběžně informovat o vlastnostech a změnách, které MKN-11 přináší, o produktech, které jsou s ní spojené a o možnostech a výhodách její implementace $v$ ČR.

Zároveň je nutné mapovat reálné potřeby a možnosti implementace MKN-11 v národně relevantních systémech a na základě podkladů a zpětné vazby provést rozhodnutí $v$ některých technických oblastech.

Vzhledem $\mathrm{k}$ tomu, že některé sektory aktuálně využívají MKN-10 spíše v její statické podobě (klasifikace, číselník), bude nutné distribuovat informaci o širších možnostech využití MKN11. Zejména v oblasti sociálně-zdravotního pomezí byla MKN $v$ jedenácté revizi výrazně rozšířena a zahrnuje nyní přesnější možnosti popisu vnějších příčin a okolností zdravotního stavu, ale také nástroje pro hodnocení funkčních schopností pacienta, což by mohlo být prínosné pro agendy Ministerstva práce a sociálních věcí ČR.

S ohledem na rozsah a preferované elektronické používání MKN-11 a zadávání dat jejím prostřednictvím se nepředpokládá vydání tištěné, knižní verze MKN-11 nebo jejích částí. V budoucnu je ovšem možné např́klad vydat v tištěné podobě (nebo jako elektronickou publikaci např. ve formě PDF) tabelární uspořádání MKN-11 MMS, tedy obdobu Tabelární části MKN 10.

Kromě jiného, česká jazyková verze MKN-11 bude součástí mezinárodních webových nástrojů pro procházení a publikaci obsahu MKN-11. Je však otázkou, zda tato forma prezentace bude představovat hlavní pilír její distribuce, nebo vzniknou další národně specifické nástroje. Jednou z možných forem distribuce je také vytvoření národního portálu pro procházení obsahu klasifikace a asistované kódování, podobně jako nyní funguje portál MKN-10 (https://mkn10.uzis.cz)).

V současné době je vzdělávání pro účely využívání a práci s MKN-10 zajištováno zejména prostřednictvím vzdělávání kodérů (navázané nyní především na metodiky vykazování diagnóz v rámci akutní lưžkové péče) a e-learningového nástroje (https://mkn vyukovy program.html). Dosavadní vzdělávací programy obsahující výuku MKN-10 budou muset být aktualizovány na MKN 11. Vzhledem k nedostatečnosti vzdělávání $v$ této oblasti obecně by měl vzniknout i prezenční kurz zaměřený na použití (kódování v) MKN-11. Cílovou skupinou, kromě kodérů, by měli být ostatní zdravotničtí pracovníci, osoby provádějící certifikaci a kódování příčin smrti nebo metodici vývoje informačních systémů pro oblast zdravotnictví (viz Tab. 2) [2].

\section{Meziresortní pracovní komise pro přípravu a koordi- naci zavedení MKN-11 v ČR}

Pro účely informovanosti, participace a komunikace $s$ aktéry zahrnutými $v$ implementaci MKN-11 v ČR byla ustanovena meziresortní pracovní komise. Komise je složena ze zástupců dotčených institucí, které používají MKN ve sběrech dat, nebo jsou angažovány v elektronizaci zdravotnictví, sběru a výměně dat ve zdravotnictví nebo na zdravotně-sociálním pomezí. Má za úkol především:

\begin{tabular}{|c|c|c|}
\hline Cílová skupina & $\begin{array}{l}\text { Forma } \\
\text { vzdělávání }\end{array}$ & Obsah \\
\hline Ambulantní lékaři & Kurz & Základy MKN-11 \\
\hline $\begin{array}{l}\text { Lékaři v lůžkových } \\
\text { zdravotnických } \\
\text { zařízeních }\end{array}$ & Kurz & $\begin{array}{l}\text { Základy MKN-11 } \\
\text { pro kódování } \\
\text { nemocnosti }\end{array}$ \\
\hline $\begin{array}{l}\text { Kodéři vykazování } \\
\text { zdravotních služeb }\end{array}$ & $\begin{array}{l}\text { Systém } \\
\text { kurzů, Ce- } \\
\text { loživotní } \\
\text { vzdělávání }\end{array}$ & $\begin{array}{l}\text { Podrobné vlast- } \\
\text { nosti MKN-11, } \\
\text { datový model } \\
\text { a kódovací sché- } \\
\text { ma, pravidla pro } \\
\text { vykazování zdra- } \\
\text { votních služeb }\end{array}$ \\
\hline $\begin{array}{l}\text { Osoby kódující } \\
\text { mortalitu }\end{array}$ & Kurz & $\begin{array}{l}\text { Pravidla pro kódo- } \\
\text { vání mortality }\end{array}$ \\
\hline Revizní lékaři & Kurz & $\begin{array}{l}\text { Podrobné vlast- } \\
\text { nosti MKN-11, } \\
\text { datový model } \\
\text { a kódovací sché- } \\
\text { ma, pravidla pro } \\
\text { vykazování zdra- } \\
\text { votních služeb }\end{array}$ \\
\hline Analytici & Kurz & $\begin{array}{l}\text { Podrobné vlast- } \\
\text { nosti MKN-11, } \\
\text { datový model } \\
\text { a kódovací sché- } \\
\text { ma, pravidla pro } \\
\text { vykazování zdra- } \\
\text { votních služeb }\end{array}$ \\
\hline $\begin{array}{l}\text { Studenti lékařství } \\
\text { a zdravotnických } \\
\text { oborů }\end{array}$ & $\begin{array}{l}\text { Součást } \\
\text { pregra- } \\
\text { duálního } \\
\text { studia }\end{array}$ & Základy MKN-11 \\
\hline
\end{tabular}

Tabulka 2 - Seznam př́slušných osob pro vyškolení v použití, obsahu a struktuře $M K N-11$

- zajistit informovanost jednotlivých institucí o 11. revizi MKN, jejich vlastnostech a dopadech na jednotlivé agendy, mezinárodních webových nástrojích a publikovaných dokumentech;

- vytvořit personální kapacity a zajistit proškolení expertů z jednotlivých institucí ve vlastnostech a struktuře MKN-11 se zaměřením na změny oproti předchozí revizi;

- zjistit konkrétní potřeby jednotlivých institucí/agend na přechod na MKN-11 včetně požadavků na technické zajištění a zjištění možných termínů přechodu na MKN-11;

- aktivně diskutovat a realizovat kroky směřující k zavedení MKN-11 v praxi, spolu se zhodnocením rizik a problémů s tím souvisejících;

- zajistit sběr námětů na akce a změny procesů nutné pro přechod na MKN-11 z jednotlivých institucí;

- identifikovat možné problémy, rizika a konflikty při implementaci MKN-11.

Komise byla ustavena 24. 11. 2020 a schází se pravidelně alespoň dvakrát ročně. Prostřednictvím diskuse na jednáních komise vznikl podrobnější přehled o tom, co pro jednotlivé instituce a agendy zavedení MKN-11 představuje a jaké kroky 


\begin{tabular}{|c|c|c|c|}
\hline Aktivita & Dílčí akce & Dotčené instituce & Časový rámec \\
\hline \multirow{5}{*}{ Příprava } & Preimplementační analýza & ÚZIS, MPK & 2021 \\
\hline & Mapování terénu & ÚZIS & $2021-2023$ \\
\hline & Identifikace potřeb & ÚZIS & $2021-2023$ \\
\hline & Tvorba a schválení Implementačního plánu & ÚZIS & 2022 \\
\hline & Aktualizace a realizace Implementačního plánu & ÚZIS & $2023-2027$ \\
\hline \multirow{6}{*}{ Český překlad } & Vytvoření české verze MKN-11 (1. verze) & ÚZIS, UK, ČLS JEP & $2021-2022$ \\
\hline & Připomínkování experty & UK, ČLS JEP & $2021-2022$ \\
\hline & Schválení a publikace 1. české verze MKN-11 & & $2021-2022$ \\
\hline & $\begin{array}{l}\text { Distribuce informace, zejména navázání kontaktu } \\
\text { s poskytovateli }\end{array}$ & & 2022 \\
\hline & $\begin{array}{l}\text { Podpora české verze (např. vypořádávání návrhů na změny } \\
\text { pro rok } R+2 \text { ) }\end{array}$ & & ročně \\
\hline & Pravidelné aktualizace MKN-11 a navazujících podkladů & & $2022-2027$ \\
\hline Oponentura "široké veřejnosti" & Nastavení aktualizačního procesu české verze MKN-11 & & $2022-2023$ \\
\hline \multirow{6}{*}{$\begin{array}{l}\text { Metodika použití MKN-11, } \\
\text { navazující další nástroje }\end{array}$} & $\begin{array}{l}\text { Iniciální Pravidla kódování, překlad doprovodných } \\
\text { dokumentů }\end{array}$ & ÚZIS & $2022-2023$ \\
\hline & Tvorba číselníků & ÚZIS & 2022 \\
\hline & Tvorba/úprava specifických manuálů & & 2022 \\
\hline & Převodník z MKN-10 na MKN-11 (příprava) & ÚZIS & 2022 \\
\hline & Bridge coding studie & ÚZIS, ČSÚ & $2022-2023$ \\
\hline & IRIS, pravidla pro výběr základní příčiny & ÚZIS, ČSÚ & $2022-2023$ \\
\hline \multirow{3}{*}{ Prezentace MKN-11 } & Identifikace možností zobrazení & & $2021-2023$ \\
\hline & Výběr nástroje pro prezentaci a distribuci & & 2023 \\
\hline & Realizace prezentačního nástroje & & $2023-2027$ \\
\hline \multirow{4}{*}{ Edukace } & Příprava vzdělávacích materiálů/nástrojů & & $2022-2023$ \\
\hline & Úvodní školení (základní principy, vzhled a struktura MKN-11) & & $2023-2024$ \\
\hline & $\begin{array}{l}\text { Detailní školení kódování dle MKN-11, specificky zaměřená } \\
\text { školení }\end{array}$ & & $2024-2025$ \\
\hline & Dlouhodobé vzdělávání & & $2024-2027$ \\
\hline \multirow{4}{*}{ Praktická implementace } & Úprava datového rozhraní NZIS a DASTA & ZP & $2022-2025$ \\
\hline & Úprava datových rozhraní zdravotních pojištoven & ÚZIS, MZ & $2023-2026$ \\
\hline & Úprava CZ-DRG & ZP, ÚZIS, MZ & $2023-2026$ \\
\hline & Úpravy informačních systémů poskytovatelů & & $2023-2027$ \\
\hline \multirow{3}{*}{$\begin{array}{l}\text { Koordinace s dalšími } \\
\text { klasifikacemi }\end{array}$} & Koordinace s MKN-O a systémy sběru onkologických dat & & $2022-2025$ \\
\hline & $\begin{array}{l}\text { Koordinace s obsahem a vydáním MKF a dalšími nástroji pro } \\
\text { popis funkčního stavu }\end{array}$ & & $2022-2025$ \\
\hline & Koordinace se systémy pro popis vzácných onemocnění & & $2022-2025$ \\
\hline \multirow{4}{*}{ Legislativa } & Zmapování relevantní legislativy, která s MKN souvisí & MZ ČR, ÚZIS & $2022-2025$ \\
\hline & Identifikace nových potřeb legislativního ukotvení & MZ ČR, ÚZIS & $2022-2024$ \\
\hline & Př́prava návrhů & MZ ČR, ÚZIS & $2024-2025$ \\
\hline & Připomínkové řízení, akceptace & MZ ČR, ÚZIS & $2025-2026$ \\
\hline
\end{tabular}

Tabulka 3 - Časová roadmapa harmonogram překladu MKN-11 do českého jazyka 


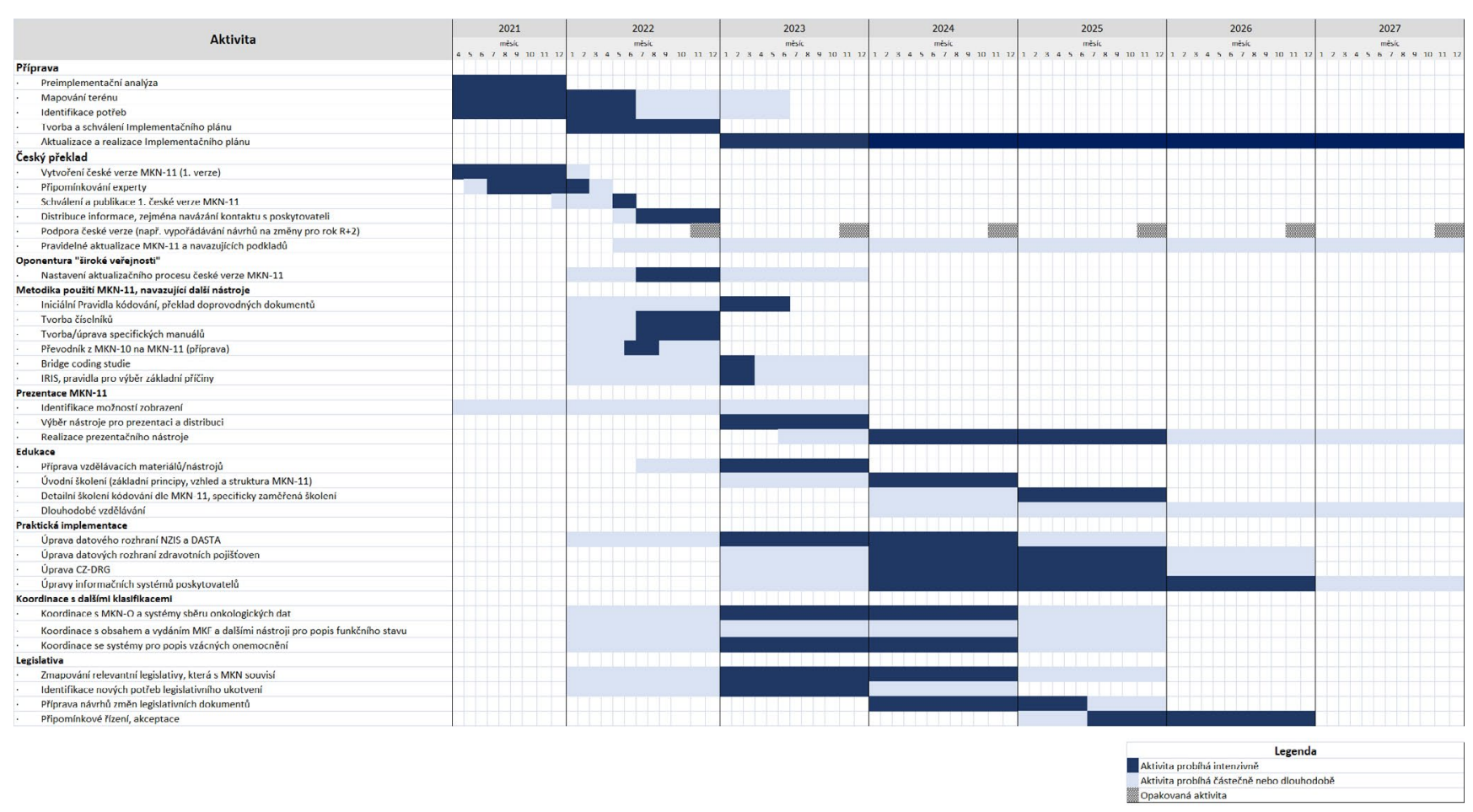

Tabulka 4 - Rozšířený podrobný harmonogram aktivit navržených v rámci implementace MKN-11 v ČR (roadmapa)

je $v$ jednotlivých oblastech nutné učinit. Byly identifikovány konkrétní aktivity a predpoklady její implementace v ČR, které uvádí Tab. 3. Podrobné navržené načasování obsažených aktivit je zpracováno v podobě Ganttova diagramu (viz Tab. 4) [2].

\section{Výzvy a problémy související s implementací MKN-11}

V souvislosti se zaváděním MKN-11 do českého prostředí se objevují problematické otázky, které je potřeba postupně řešit a reagovat na ně. Je žádoucí rozhodnout, na jaké úrovni bude MKN-11 v ČR implementována, zda na úrovni MMS, „národní linearizace vytvořená de novo nebo odvozením od MMS nebo Foundation.

V úvahu připadá jednotné systémové nebo individualizované zavedení MKN-11 podle jednotlivých agend. Výhody první možnosti jsou jednodušší vzájemné ověření výstupů mezi agendami bez převodů nebo přepočtů, unifikace školení a výuky uživatelů, unifikace metodik, snazší používání na úrovni SW (nemusely by obsahovat různé verze pro stejná období platnosti). Riziky s tím spojenými jsou náročnost synchronizace zavedení ve více agendách a institucích, kumulace nárůstu administrativní, resp. pracovní zátěže, pokud se nepodaří nebo nestihne zavedení elektronických nástrojů a adaptace procesů primárního zápisu dat (lékaři, kodérii), kumulace investic do centrálních informačních systémů (centrální instituce), zvýšená časová náročnost hromadné implementace, problém při zavádění $v$ jakékoliv agendě by mohl zabrzdit nebo jinak negativně ovlivnit proces zavádění, možné různé potřeby jednotlivých institucí (zavedení $v$ různých agendách může souviset $\mathrm{s}$ různým mezinárodním využitím dat a možnými povinnostmi danými mezinárodními institucemi např. WHO, Eurostat).

WHO vyvinula sadu webových nástrojů pro distribuci MKN11 a asistované kódování (práci s klasifikací, vyhledávání kódů v MKN-11 MMS), včetně rozhraní API pro integraci do systémů třetích stran $v$ online i offline režimu. Po vytvoření české verze MKN-11 bude možné tyto nástroje využívat i pro práci s českou verzí MKN-11. Zároveň je možné na základě struktury klasifikace vytvořit online nástroje pro distribuce české verze MKN-11 na národní úrovni. Mohlo by se jednat o prohlížeč klasifikace
"Coding Tool", tedy fulltextové vyhledávání termínů v klasifikaci MKN-11, resp. ve vrstvě Foundation nebo národní rozhraní API $s$ rozšírenými službami. Přidanou hodnotou by mohly být další kontextově napojené zdroje a služby, které mezinárodní nástroje WHO neobsahují, například národní metodiky pro vykazování mortality nebo pro vykazování morbidity pro potřeby DRG. Další výhodou by byla nezávislost na dostupnosti produktů WHO a omezení rizik z ní vyplývajících, např́iklad pro nedostatečnou kapacitu mezinárodních služeb nebo prípad výpadku mezinárodní služby. Nevýhodou by byla nutnost vývoje těchto národních řešení, jejich dlouhodobá správa, údržba a nezávislá aktualizace. Vzorem pro národní nástroje $\mathrm{kMKN}-11$ by mohl být nový národní portál k české verzi MKN-10 [2].

\section{Mezinárodní spolupráce}

Vzhledem $\mathrm{k}$ tomu, že $\mathrm{s}$ prekladem a zavedením MKN-11 se potýkají i další státy, je velmi důležité a prínosné tento proces monitorovat a sdílet i na mezinárodní úrovni. ÚZIS ČR je nyní $v$ kontaktu se zahraničními institucemi, jednak v rámci WHO Family of International Classification Network, jednak bilaterálně především se Slovenskem, Německem, Nizozemím a Polskem. Obsahem těchto komunikací je sdílení zkušeností s přípravou a vytvářením národních verzí MKN-11 a s prípravou na její zavedení.

V souvislosti s implementací MKN-11 a podporou členských států pořádalo WHO v roce 2020 dva online webináře, kterých se zúčastnili zástupci ÚZIS ČR a několik dalších zástupců ze spřízněných institucí. S WHO probíhají také podpůrné konzultace týkající se problematiky překladu MKN-11. Zároveň byla Světovou zdravotnickou organizací zahájena iniciativa vytvoření prostoru pro evropské státy pro sdílení zkušeností s prípravou a implementací MKN-11 (a dalších klasifikací) v jednotlivých zemích.

Jak bylo zmíněno výše, ÚZIS ČR zahájil v rámci přípravy české verze MKN-11 spolupráci se Slovenskem. Vzhledem k jazykové př́buznosti češtiny a slovenštiny se nabízí i užší spolupráce na překladech. Do spolupráce by bylo do budoucna možné zahrnout validaci částí překladu oproti druhému jazyku, kon- 
trolu kompletnosti synonym nebo identifikaci sporných bodů a jejich vzájemnou konzultaci (např. terminologické konflikty mezi odbornostmi). V průběhu let 2020 a 2021 bylo realizováno několik telekonferenčních hovorů se zástupci Národného centra zdravotníckych informácií s výměnou zkušeností s prípravou národních verzí MKN-11 [2].

\section{Závěr}

Vytvoření české verze $M K N-11$ a její zavedení do českého zdravotnického systému umožní větší podrobnost záznamu zdravotnických informací o pacientovi, tím i statistických výstupů a analýz zdravotnických dat nad rámec současných možností. $\mathrm{S}$ implementací dojde $\mathrm{k}$ rozšíření struktury a informačních možností MKN-11 a k lepšímu a podrobnějšímu popisu zdravotního stavu. MKN-11 bude také vhodnější k použití v aplikacích elektronického zdravotnictví a při konstrukci strukturovaného elektronického zdravotního záznamu. $V$ neposlední řadě MKN11 umožní analýzu a srovnání dat napříč uživateli jednotlivých států a tím otevře cestu mezinárodnímu sdílení a porovnávání.

ÚZIS ČR připravuje českou verzi MKN-11 založenou na překladu a adaptaci mezinárodního vzoru vytvořeného Světovou zdravotnickou organizací. Tvorba české verze MKN-11 je zprostředkována $v$ těsné spolupráci se zástupci klinických oborů nominovaných odbornými společnostmi tak, aby byla zajištěna přesnost klinické terminologie a kompletnost klinického obsahu.

Pro vytváření české verze jsou používány mezinárodní webové nástroje a oběh obsahu v podobě tabulek. Dokončení první české verze MKN-11 je naplánováno na rok 2022 a následně bude spuštěn pravidelný aktualizační proces. Dále bude navazovat testování obsahu a další kroky směřující k implementaci MKN-11 v České republice.

\section{Literatura}

[1.] Přispěvatelé WikiSkript, Mezinárodní klasifikace nemocí [online], c2020, Datum poslední revize 9. 02. 2020, 18:44 UTC, [citováno 16. 08. 2021] <https://www.wikiskripta.eu/index.php?title=Mezin\%C3\%A1rodn\%C3\%AD klasifikace nemoc\%C3\%AD\&oldid =434791>

[2.] ZVOLSKÝ, M., Daňková, Š., KREJČOVÁ, D., Preimplementační analýza, Ústav zdravotnických informací a statistiky ČR, Praha, 2019

[3.] ICD-11 Implementation or Transition Guide, Geneva: World Health Organization; 2019; License: CCBY-NC-SA3.0IGO.

[4.] ICD-11 Reference Guide, Geneva: World Health Organization; 2019.

[5.] Eleventh revision of the International Classification of Diseases, Report by the Director-General; Document No. EB144/22; Executive Board; 144th session; 12 December 2018.

[6.] Tu S. W. et al. (2010): A Content Model for the ICD-11 Revision.

\section{PREPARATION OF THE CZECH VERSION OF THE 11TH REVISION OF THE INTERNATIONAL CLASSIFI- CATION OF DISEASES}

\section{Dana Krejčová, Miroslav Zvolský, Šárka Daňková}

has been assembled from representatives of key institutions in the implementation process to ensure the transfer of information from individual institutions, provide basic training to key persons from individual institutions, identify specific needs of individual institutions/agencies for the transition to ICD-11 and take steps to implement it in practice. An internal team of 12 members is working on the translation of ICD-11 starting in summer 2020 in collaboration with experts from the Institute of History of Medicine and Foreign Languages to ensure correct terminology and linguistic consistency. The first phase of the translation is being carried out using the World Health Organization's (WHO) ICD-11 platform and is scheduled to be finalized in late 2021/early 2022. Validation and verification of translated chapters of the Czech version of the ICD-11 is being carried out in collaboration with experts nominated by the Czech Medical Society of J. E. Purkyně, and in the final phase, individual chapters will be reviewed by other institutions such as the Ministry of Health of the Czech Republic and the Czech Statistical Office. The completion of the Czech version of ICD11 and subsequent revisions is planned for 2022. The efforts to implement ICD-11 in the Czech Republic have also led to international cooperation activities with other countries (Poland, Slovakia) and closer cooperation with the WHO.

\section{Keywords}

International Classification of Diseases, Translation, ICD-11, Implementation, Medical Terminology

\section{Kontakt}

Ing. Dana Krejčová

Ústav zdravotnických studií a statistiky ČR, Palackého nám. 4, 12801 Praha 2

tel: +420739465914

e-mail:dana.krejcova@uzis.cz

MUDr. Miroslav Zvolský

Ústav zdravotnických studií a statistiky ČR, Palackého nám. 4, 12801

Praha 2

tel: +420604905058

e-mail: miroslav.zvolsky@uzis.cz

RNDr. Šárka Daňková

Ústav zdravotnických studií a statistiky ČR, Palackého nám. 4, 12801

Praha 2

tel: +420224972887

e-mail:sarka.dankova@uzis.cz

\begin{abstract}
The Institute of Health Information and Statistics of the Czech Republic within the project of the National Centre for Medical Nomenclature and Classification is working on the process of implementation of ICD-11 into the Czech health care system. For this reason, a Preimplementation Analysis has been created to serve as an information basis for decision-making on the implementation of ICD-11 in the Czech Republic, setting time estimates, planning capacities and resources, developing necessary procedures, etc. An inter-ministerial working committee
\end{abstract}

